\title{
PADRONIZAÇÃO DA NESTED PCR EM TUBO ÚNICO (STNPCR) PARA DETECÇÃO DE CIRCOVÍRUS SUÍNO 2 NO FLUIDO ORAL DE SUÍNOS
}

\author{
D. G. ARAÚJO ${ }^{1}$, M. R. BARROS JÚNIOR ${ }^{1}$, C. N. BARBOSA ${ }^{2}$ e A.C. FREITAS ${ }^{1}$ \\ ${ }^{1}$ Universidade Federal de Pernambuco, Centro de Ciências Biológicas, Laboratório de \\ Estudos Moleculares e Terapia Experimental (LEMTE). \\ ${ }^{2}$ Universidade Federal Rural de Pernambuco, Departamento de Medicina Veterinária. \\ E-mail para contato: dany_melo_@hotmail.com
}

\begin{abstract}
RESUMO - Este trabalho teve como objetivo padronizar a STNPCR para detectar o Circovírus Suíno 2 a partir de amostras de fluido oral de suínos. Foram coletadas 55 amostras de fluido oral de suínos clinicamente saudáveis. O DNA foi extraído e quantificado para realização da PCR convencional e STNCR. Para garantir a segurança e confiabilidade dos resultados, uma PCR direcionada para o gene da $\beta$-actina foi realizada em todas as amostras. Todos os fragmentos amplificados foram analisados através de eletroforese. A padronização da técnica de STNPCR é uma ferramenta útil para a identificação da presença do PCV2, que pode contribuir na redução do impacto econômico que este problema representa para a suinocultura industrial.
\end{abstract}

Palavras-chave: Circoviroses. Suinocultura. PCV2.

\begin{abstract}
This work aimed to standardize the STNPCR to detect Porcine Circovirus 2 from swine oral fluid samples. 55 samples of oral fluid from clinically healthy pigs were collected. DNA was extracted and quantified for the performance of standard PCR and STNCR. To ensure the safety and reliability of the results, a PCR targeted to the $\beta$-actin gene was performed on all samples. All amplified fragments were analyzed by electrophoresis. A standardization of the STNPCR technique is a useful tool to identify the presence of PCV2, which may contribute to reducing the economic impact of this problem for a Swine Breeding industry.
\end{abstract}

Keywords: Circovirosis. Swine Breeding. PCV2.

\section{INTRODUÇÃO}

O Circovírus suíno do tipo 2 (PCV2) é um agente que possui um papel importante nas perdas econômicas em granjas de suínos através da queda no desempenho e morte desses animais, o que evidencia a importância de se realizar estudos a respeito deste vírus, buscando direcionar uma maior atenção quanto às práticas de controle da infecção e, dessa forma, diminuir as perdas econômicas para os produtores. 
Os registros na literatura revelam que amostras de fluido oral (FO) já foram investigadas para triagem de anticorpos e patógenos de suínos, podendo substituir as amostras de sangue em testes de diagnóstico (BARBOSA et al., 2013). Nesse contexto, o método das cordas de algodão para obtenção do FO torna-se uma ótima alternativa para a coleta, uma vez que trata-se de um método não invasivo e indolor. Prickett e Zimmerman (2010) demonstraram a eficácia da aplicação desse método para obtenção do fluido oral dos suínos, bem como as técnicas de diagnósticos a base do fluido oral.

A Nested PCR em tubo único (STNPCR) tem sido desenvolvida e aplicada com êxito para diagnóstico de patógenos humanos e animais, sendo esta uma técnica com maior sensibilidade de detecção, se comparada com a PCR convencional (ABATH et al., 2002; SOUZA et al., 2007). A padronização desta técnica para a identificação da presença do PCV2 será de grande importância para suinocultura da região. Sendo assim, este trabalho teve como objetivo padronizar a STNPCR para detectar o Circovírus Suíno 2 a partir de amostras de fluido oral.

\section{MATERIAIS E MÉTODOS}

Foram coletadas 55 amostras de fluido oral de suínos clinicamente saudáveis, conforme a Barbosa e colaboradores (2013). Em seguida, as amostras foram devidamente identificadas, acondicionadas em gelo e transportadas ao laboratório. O DNA total foi extraído pelo kit comercial Wizard ${ }^{\circledR}$ (Genomic DNA Purification - Promega, EUA), quantificado com o auxílio do equipamento NanoVue (GE, Alemanha) e armazenado a $-20^{\circ} \mathrm{C}$ até a realização das análises. A PCR convencional e a NPCR foram realizadas conforme descrito por Kim et al. (2001), e a técnica de STNPCR foi realizada conforme descrita por Souza et al. (2007), com alterações, uma vez que essa técnica foi aplicada em tecidos, e no presente estudo objetiva-se padronizá-la para o fluido oral. Para garantir a segurança e confiabilidade dos resultados obtidos, uma PCR direcionada para o gene da $\beta$-actina foi realizada em todas as amostras. Todos os fragmentos amplificados foram analisados através de eletroforese em gel de agarose à $2 \%$ corados com brometo de etídeo.

\section{RESULTADOS E DISCUSSÃO}

Para o gene da $\beta$-actina, optou-se por usar as concentrações dos primers de $0,24 \mu \mathrm{M}$, enquanto que a temperatura de anelamento foi padronizada em $58^{\circ} \mathrm{C}$, e o número de ciclos foi 30. O desenvolvimento desta técnica resultou na amplificação de um produto de $478 \mathrm{pb}$ (Figura 1). A técnica foi aplicada nas 55 amostras, sendo positiva em 100\%, o que assegura a viabilidade do DNA contido nas mesmas.

Figura - Gel representativo da PCR direcionada ao gene da $\beta$-actina. MM: $1 \mathrm{~kb}$ DNA ladder; Canaletas 4-8: amostras de FO de suínos; CP: controle positivo de referência; $\mathrm{CN}$ : controle negativo de reação (água).

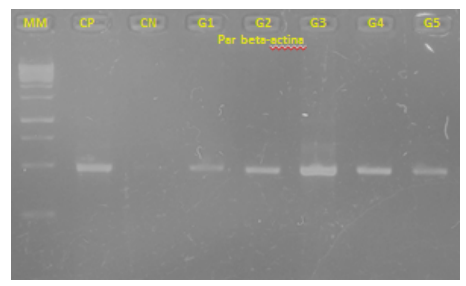


A utilização de uma PCR direcionada ao gene da $\beta$-actina apresenta notável importância ao permitir que a avaliação da eficiência do DNA extraído, excluindo os falsos negativos, que podem ser decorrentes da não recuperação do DNA viral na extração, da falta de integridade do DNA ou por possíveis fatores de inibição da PCR (CASTRO et al., 2013).

Para a STNPCR, foi padronizada a concentração de primers externos e internos de $0,04 \mu \mathrm{M}$ e $0,4 \mu \mathrm{M}$, respectivamente. As temperaturas de anelamento foram padronizadas em $62^{\circ} \mathrm{C}$ e $63^{\circ} \mathrm{C}$, respectivamente. Quanto aos números de ciclos foram 15 e $45 \operatorname{nos} 1^{\mathrm{o}}$ e $2^{\mathrm{a}}$ estágios. O desenvolvimento da técnica resultou em amplificação do produto esperado de 225 pb relativo ao PCV2 (Figura 2). Até o presente momento, a técnica foi aplicada em 5 amostras, das quais $100 \%$ foram positivas, confirmando a presença de PCV2 nas mesmas. $\mathrm{O}$ sequenciamento dos produtos de PCR foi utilizado para validação da presença de PCV2 nas amostras avaliadas.

Figura 2- Gel representativo da STNPCR. MM: 1kb DNA ladder; CNR: controle negativo de referência (amostras sabidamente negativas); CP: controle positivo de referência (ORF do PCV); CN: controle negativo de reação (água); G5: amostra de FO de suíno.

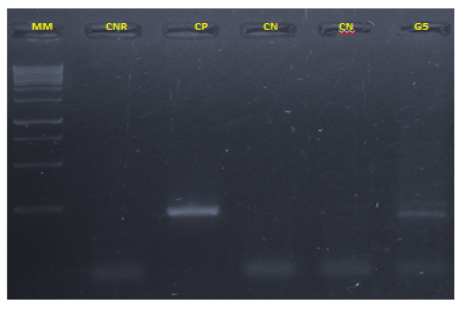

Outros estudos demonstram a aplicação e elevada sensibilidade da STNPCR em outros tipos de organismos (ABATH et al., 2002; SOUZA et al., 2007). A literatura mostra ainda que a STNPCR já foi aplicada com sucesso para a detecção de PCV2 em amostras de tecido de suínos (PONTES et al. 2014). A Nested PCR apesar de mais sensível que a PCR convencional, apresenta um maior risco de contaminação das amostras devido à abertura do tubo contendo o produto da primeira fase para que se possa dar início à segunda etapa. Porém, quando se trata da STNPCR, Abath et al. (2002) e Souza et al. (2007), evidenciaram que a contaminação cruzada é drasticamente reduzida, devido à fixação do segundo par de primers na parte interna da tampa do tubo. Nossos resultados corroboram com estas observações, uma vez que não foram evidenciadas contaminações cruzadas.

\section{CONCLUSÃO}

O achado de PCV2 em suínos clinicamente saudáveis foi um achado importante, visto que esse agente viral representa um problema para suinocultura industrial. A padronização da técnica de STNPCR para a identificação da presença do PCV2 constitui uma ferramenta importante para a suinocultura da região, uma vez que a detecção do vírus representa uma redução no expressivo impacto econômico por meio da detecção do vírus.

\section{REFERÊNCIAS}

ABATH, F.G.C.; MELO, F.L.; WERKHAUSER, R.P.; MONTENEGRO, L.; MONTENEGRO, R.; SCHINDLER, H.C. Single-tube nested PCR using immobilized internal primers. Biotechniques. 33, 1210-1214. 2002. 
BARBOSA, C. N.; FREITAS, T.R.P. Implementação da técnica de imuno-histoquímica (IHQ) para o diagnóstico do circovírus suíno tipo-2 (CVS-2). R. Cien. Med. Biol. 7, 211219. 2013.

CASTRO, A.M.M.G.; CASTRO JÚNIOR, F.G.; MORI, C.K.; CRUZ, T.F.; BALDIN, C.M.; BUDINO, F.E.L.; ARAÚJO JÚNIOR, J.P.; RICHTZENHAIN, L.J. Obtenção de animais negativos para Circovírus suíno 2 oriundos de granjas positivas: estratégia de manejo. Arq. Inst. Biol. 80, 4, 393-399. 2013.

KIM, J.; HAN, D.U.; CHOI C.; CHAE, C. Differentiation of porcine Circovírus (PCV)-1 and PCV-2 in boar semen using a multiplex nested polymerase chain reaction. J Virol Methods. 98:25-31. 2001.

PONTES, N.E.; BARBOSA, C.N.; JESUS, A.L.S.; SILVA, J.G.; FREITAS, A.C. Development and evaluation of single-tube Nested PCR (STNPCR) for the detection of Porcine Circovirus type 2 (PCV2). Transb Emerg Diseases. 61: 233-238. 2014.

PRICKETT, J.R.; ZIMMERMAN, J. The development of oral fluid-based diagnostics and applications in veterinary medicine. An Health Res Rev. 11, 207-216. 2010

SOUZA, G.; ABATH, F.G.C.; LEAL, N.C.; FARIAS, A.; ALMEIDA, A. Development and evaluation of a single tube nested PCR based approach (STNPCR) for the diagnosis of plague. Adv. Exp. Med. Biol. 603, 351-359. 2007.

\section{AGRADECIMENTOS}

Ao Laboratório de Estudos Moleculares e Terapia Experimental da UFPE, pela disponibilidade dos equipamentos e insumos utilizados nesta pesquisa, e à CAPES (Coordenação de Aperfeiçoamento de Pessoal de Nível Superior) pela concessão da bolsa durante o período de realização deste mestrado. 